\title{
Drivers of community participation in heritage tourism planning: an empirical investigation
}

\author{
Mina Dragouni \& Kalliopi Fouseki \\ UCL Institute for Sustainable Heritage, London, UK
}

\begin{abstract}
Despite increased emphasis on community participation in tourism planning, our current knowledge of community attitudes and their motivations to engage in such collaborative governance is limited and fragmented. This paper explores the role of heritage values, tourism and community perceptions held by destination hosts as drivers to willingness to participate in heritage tourism development. Such enquiry aims to enhance our current knowledge of community views and their potential to influence involvement in participatory decision-making in order to inform policy approaches to collaborative heritage tourism strategies. Using a relatively inexperienced destination community (Kastoria, Greece), the study collects quantitative data via an attitudinal survey. Our findings suggest that intentions to participate are mainly driven by community ideals while their positive influence is more evident on community members with high place attachment. Heritage values play a significant role; however, their effects do not always favour participation as they can also act as barriers to involvement. On the other hand, tourism perceptions are found to be mainly insignificant in shaping intentions to participate. Finally, the paper presents and discusses variations between different demographic groups and draws implications for policy.
\end{abstract}

\section{Introduction}

This paper aims to investigate the factors that motivate or demotivate community participation in heritage tourism planning, using an attitudinal survey instrument. In particular, the study seeks to 
disentangle the role of heritage values, tourism expectations and the wider societal context in driving willingness to participate (WTP), as identified through semi-structured interviews with local stakeholders and a cross-disciplinary review of the literature, and expressed empirically by questionnaire data. Such enquiry is timely as in recent years research on heritage tourism proliferated (see inter alia Bessiere, 2013; Dines, 2016; Suchet \& Raspaud, 2010; Wu, Xie, \& Tsai, 2015), whereas collaborative decision-making and bottom-up approaches are increasingly understood as critical to sustainable tourism development in both academia (Cohen-Hattab, 2013; Su \& Wall, 2014; Waligo, Clarke, \& Hawkins, 2013) and international policy (UNESCO, 2012; UNWTO, 2008).

Heritage tourism is a type of special interest tourism where visitors experience the local heritage of destinations as manifested by archaeological sites, historic landscapes, local architecture, museums, art expressions, traditions and practices resourced from the past (Timothy \& Nyaupane, 2009). Although not exclusively, heritage tourism has become particularly relevant to culturally rich and remote regions that wish to stimulate growth and compensate for their depressed primary and secondary industry sectors (Smith, 2009b). In this respect, heritage tourism is an economic solution that promises to bridge conservation and development by highlighting the economic value of heritage resources. Nevertheless, the building of a lucrative and viable heritage tourism sector is challenging, as it presupposes collaborative strategies and the balancing of growth with social equity and environmental quality - both ecological and cultural (Landorf, 2009; Nunkoo \& Ramkissoon, 2011).

Among other vital steps towards successful and sustainable heritage tourism operations, decisionmaking polyphony and multi-stakeholder approaches to planning are largely considered as important elements of realizing sustainability, proposing the active involvement of destination communities in the design of tourism strategies (see among others, Kimbu \& Ngoasong, 2013; Li 
\& Hunter, 2015; Pacifico \& Vogel, 2012; Su \& Wall, 2014). The advocates of this proposition suggest that the benefits of participatory governance would be numerous, including the higher legitimacy of tourism policies (Hall, 2007), the more rightful share of tourism gains and costs (Sofield, 2003), and the cultivation of synergies that enhance heritage interpretation, hospitality atmosphere and social capital (Nunkoo \& Ramkissoon, 2011; Okazaki, 2008).

Despite the growing consensus on participatory tourism planning, there is presently little knowledge of how policy-makers can approach and engage communities in decision-making effectively (Ashley, Osmani, Emmitt, Mallinson, \& Mallinson, 2015). Although participatory tourism models place most emphasis on the definition and management of stakeholders (e.g. Johnston \& Tyrrell, 2008; Waligo et al., 2013), in actu experience highlights several other complications that undermine its application, including practical and ideological barriers (Aas, Ladkin, \& Fletcher, 2005; Marzuki, Hay, \& James, 2012), the difficulties of maintaining community involvement on a long-term basis (Dodds, 2007; Svensson, 2015), and a frequent gap between participation and the generation of benefits that are appreciated collectively (Simpson, 2008). At the same time, tools that explore community perceptions (e.g. Byrd, Bosley, \& Dronberger, 2009; Currie, Seaton, \& Wesley, 2009) seek to inform development decisions but are disconnected from participatory approaches.

Given that community WTP should not be taken for granted, it is proposed that the management of heritage through community-based research could form a paradigm of practice towards a more community-inclusive heritage tourism planning. This paradigm positions communities and their aspirations at the heart of its enquiry, emphasizing questions that revolve around the public understandings of heritage, the identification of community needs and the accommodation of these needs through community involvement (Atalay, 2010; Stephens \& Tiwari, 2015). It is held that such an approach is better positioned to balance expert with local knowledge from the very 
beginning, address community-specific demands more effectively and make collective actions that would be more relevant to destination hosts.

As Fan (2014) and Perkin (2010) argue, the understanding of community incentives and needs is vital for embarking on community-driven projects. Therefore, it is maintained that participatory strategies need to depart from community attitudes, taking cognizance of existing meanings and perceptions of local heritage, tourism and the community itself. This would allow the identification of those elements that have the capacity to influence participation in heritage tourism and thus inform engagement and communication strategies that could be maintained on a long-term basis. We specifically suggest that the heritage management values framework and our current knowledge from community-based participatory research within the heritage field could critically enhance present work on participatory tourism. We further propose the linking of tourism perception studies with collaborative decision-making over heritage tourism planning as a means of informing policy approaches to community engagement.

Based on these premises, the present study combines the values-based approach to heritage management with tourism perceptions and community-specific qualities, with the view to explore empirically the factors that drive community intensions towards participatory policy-making for the shaping of the local heritage tourism agenda. We provide empirical evidence on this critical issue through an attitudinal survey at Kastoria, Greece, an area that is ideal for the evaluation of an immature participatory environment, where both heritage tourism development and community involvement in its planning and management are at their infancy.

\section{Factors influencing WTP}

Community participation in heritage tourism planning is a particularly complex and multifaceted issue, which can be better explored through a synthesis of approaches and knowledge generated 
within both the heritage and tourism fields. For this reason, our enquiry into the drivers of community behaviour builds and tests a broad set of factors that are likely to influence participatory dynamics and WTP, based on scholarly and practice-based literature.

Starting from heritage studies, we adopt the values-based model, an approach of increasing importance in heritage conservation, planning and management (de la Torre, 2013; Walter, 2014). Values are best defined as socially constructed meanings and as actual or potential qualities attached to heritage assets (Mason, 2002). These qualities are particularly diverse (e.g. aesthetic, scientific, spiritual) and can exhibit much heterogeneity due to their dynamic and subjective character that is place and time-specific (for a historic development of value typologies see McClelland, Peel, Hayes, \& Montgomery, 2013). Despite their intrinsic and dynamic character, heritage values permeate a plethora of decisions associated to heritage practice (de la Torre, 2013), whereas ultimately, the rationale of the values approach is the identification of the societal reasons for investing in heritage (Worthing \& Bond, 2007). Community-based research on this area suggests that cultural heritage is most commonly invested with social, symbolic and identity attributes, historic associations and a sense of connection to place and the past (Fouseki \& Sakka, 2013; Mydland \& Grahn, 2012; Smith, 2009a).

The need for assessing heritage significance is also relevant to heritage tourism decisions. In fact, the values-based approach is considered particularly useful to collaborative planning practices and an approach that has the capacity to improve community engagement and promote more inclusive planning frameworks (Mason, 2006). The basis of using the values-based approach in participatory heritage tourism is for understanding the ways through which such development could be relevant to its community while capturing the reasons for stakeholders' engagement in collaborative planning. Values inscribed in local heritage can be defined in terms of the personal and communal importance that community members attach to the heritage assets of their area (Dillon et al., 2014). 
Based on the aforementioned, it is important to first evaluate the role of heritage values on community behaviour and in particular, to establish a relationship between the former and intentions to participate, in order to inform engagement policy. It is plausible to assume that the nature of heritage values and the degree to which a destination community acknowledges them as important may impact their participation. Thus, it is interesting to explore the connection between to WTP and heritage values and to test whether the latter would stimulate community involvement. This leads us to propose our first hypothesis:

H1. Heritage values drive W'TP in heritage tourism planning.

In parallel, it is valuable to investigate community aspirations with regard to heritage tourism development (actual and potential) and whether these influence, either positively or negatively, their future involvement in heritage tourism planning. Tourism impacts are commonly classified as economic (e.g. invigoration of local economy, employment), socio-cultural (e.g. capacity building, development of infrastructure and services) and environmental (e.g. preservation of local heritage and local arts/crafts) (Simpson, 2008; Wall \& Mathieson, 2006). Although impacts have both positive and negative sides (e.g. opportunity costs and rise of prices, deprived access, environmental degradation, commodification or standardization), communities of non-mature destinations frequently visualize (potential) positive impacts at a greater degree than (potential) negative consequences (Reid, Mair, \& George, 2004).

Thus, when dealing with emerging destinations and future tourism development, it is more appropriate to investigate the influence of desirable tourism change on community behaviour. Based on this premise, a reasonable hypothesis to test is whether expectations of (positive) tourism impacts motivate WTP, as a way to influence and drive policy towards the realization of anticipated benefits. This enquiry will help establishing a link between intentions to participate and expected 
tourism effects. Based on the aforementioned, our second hypothesis is the following:

H2. Expectations of positive tourism impacts exert a positive influence on WTP in heritage tourism planning.

Further, community-based participatory research highlights that local environment and place are also likely to affect the initiation and continuity of participation, rendering it important to also assess the broader societal context of community involvement (Brodie et al., 2011; Frank \& Smith, 2000; Giachello, 2007). Perceptions of place and community, local political culture and local priority issues are key ingredients in the formalization and maintenance of community-based collaborations (Brodie et al., 2011). For instance, trust, cohesiveness and current community ties can form a fertile ground for establishing collective action (Giachello, 2007; Nunkoo \& Ramkissoon, 2011). At the same time, perceptions of impact, i.e. the degree to which community is convinced that their action could meaningfully affect policy, can be another catalyst to WTP (Brodie et al., 2011).

Therefore, it is important to also take into consideration these parameters and explore whether they influence community behaviour towards participation. Our hypothesis is that communityspecific elements that shape social fabric, such as place attachment and societal relationships along with confidence in the value-adding capacity of collaborative planning, would all affect WTP positively. This leads us to our third testable hypothesis:

H3. Community ideals affect WTP in heritage tourism planning positively. 
As illustrated on Figure 1, our framework of enquiry has three different dimensions, drawing from heritage values, tourism perceptions and community-based participatory studies. It is held that deconstructing the role that these factors play in driving community attitudes towards involvement in heritage tourism planning could contribute both methodologically and practically to our knowledge of designing effective participatory strategies for heritage tourism.

\section{Survey design}

The context of the present study is Kastoria, a peripheral region in the northern peninsular mainland of Greece. Kastoria presents several characteristics that make its development of sustainable heritage tourism relevant and timely: (i) it is rural and isolated, (ii) it has a depressed economy due to its declined manufacturing, (iii) it features a rich collection of heritage assets, including archaeological sites, medieval monuments and traditional architecture and (iv) its tourism sector is currently developing and could gain a competitive edge by focusing on special interest heritage tourism. Given the dramatic raise of unemployment rate in the area (as high as 30\% according to the Hellenic Statistical Authority, 2016) and the vulnerability of its heritage capital (it is characteristic that its historic centre featured in Europa Nostra list of the 7 Most Endangered Heritage Sites in Europe'; Council of Europe Development Bank, 2015), the development of viable solutions that could serve both its economic and heritage ends is of critical importance.

Although local administrators and citizens view such potential in heritage tourism operations, policy-wise, little has taken place in terms of planning for heritage tourism and engaging community in the design of a local heritage tourism strategy. Acknowledging the significance of sustainable heritage tourism for the area, the survey placed its emphasis on three main sets of parameters: (a) heritage values, (b) tourism impacts and aspirations and (c) local environment and perceptions of community, to inform its future policy. The purpose was to evaluate the impact of 
these sets of parameters on community attitudes towards participation (i.e. drivers and barriers to participation) and in particular, their willingness to take on an active role in the strategic design of heritage tourism in their area, while also considering respondents' personal circumstances (i.e. demographic profile and resources).

More specifically, the questionnaire comprised a set of 51 Likert scale attitudinal statements with a 7-point rating scale from totally disagree to totally agree. In general, attitudinal statements express respondents' viewpoints, beliefs, preferences, feelings or positions towards a particular sentence (Oppenheim, 2001). This survey approach is common in tourism studies (e.g. Andereck, Valentine, Knopf, \& Vogt, 2005; Sharma \& Dyer, 2009) and can be further used to explore perceptions of heritage tourism and their effect on participation.

Statement items were based on qualitative data and desk research. The former were collected through 25 semi-structured interviews with representatives from key stakeholder groups (i.e. residents, members of local community associations, tourism professionals chosen through convenient random sampling and heritage experts and government officials approached through quota sampling) conducted at Kastoria to inform questionnaire design (Dillon et al., 2014; Fouseki \& Sakka, 2013). The interviews aimed to elicit personal and comparative statements of value through exploratory questions associated with interviewees' perceptions of heritage and tourism, their relationship with community and place, and their attitude towards participation. Most relevant data were subsequently extracted from the interview transcripts and grouped into themes (i.e. heritage values, tourism and community/place perceptions) (Bernard, 2011). The questionnaire was also enriched by statements composed based on the relevant literature on heritage values, tourism impacts and community participation (e.g. Brodie et al., 2011; Mason, 2002; Wall \& Mathieson, 2006). WTP was measured by a binary variable that asked respondents to state whether they wanted or not to be involved in heritage tourism planning and management. 
In addition, the survey featured a section of demographic questions with the view to gain an additional insight into respondents' personal circumstances and how these might differentiate their WTP. Apart from gender and age, questionnaire items sought to collect information about respondents' practical (e.g. time, income) and learnt resources, such as education level and field of study (Brodie et al., 2011; Frank \& Smith, 2000). Moreover, it was meaningful to collect profile information that related to stakes in heritage tourism development, including professional/economic dependency on tourism and/or heritage, place of residence and attachment to community and place measured by birthplace, years of residency at Kastoria, membership to local cultural groups/associations or other formal or informal modes of participation that contribute to the promotion of local heritage. All demographic characteristics were measured as categorical variables.

A face-to-face delivery of the questionnaire occurred in Kastoria between July and November 2015. The sample included community members aged over 18 that lived or worked in the studied area on a permanent basis or they otherwise had some common interests in the place (e.g. origins and family ties). Respondents were chosen on the basis of simple random and convenience sampling. All respondents maintained their anonymity.

\section{Data and preliminary findings}

Overview of responses

In total, 665 of the collected responses were valid for statistical analysis. Based on the Krejcie and Morgan's (1970) sample size determination matrix and Kastoria's population (50,322 residents; Hellenic Statistical Authority, 2011), the minimum number of representative sample should be 381 (Lwoga, 2016). Thus, our sample size is highly representative of the host community. Demographic-wise, the sample comprised $53.1 \%$ male respondents, with median age ranging from 35 to 44 years. Further, 91\% of respondents held at least a high school diploma, 51.9\% were in 
full-time employment and $63.9 \%$ had lived in Kastoria for more than 20 years. Positive responses towards WTP in heritage tourism planning equalled $63.2 \%$ of the sample.

In terms of attitudes, respondents generally showed a high appreciation for local heritage. However, the community's evaluation of heritage assets complied largely with Smith's (2006) 'authorised heritage discourse', as statements referring to the material heritage that is officially recognized as significant (e.g. archaeological remains and medieval sites) exhibited much less differentiation in responses (i.e. commonly ranked high/very high) compared to statements referring to intangible and more folk elements (e.g. the local traditional carnival), which exhibited greater variation (i.e. from very low to very high). Moreover, responses towards tourism impacts showed optimism about high positive and low negative effects, in accordance to the literature (Reid et al., 2004), although there was much less confidence in the degree to which these effects would be relevant to community at a practical level (e.g. increase their job opportunities).

\section{Heterogeneity across subsamples}

It is important to examine intentions towards participation based on respondents' demographic characteristics and personal circumstances. More specifically, we need to explore whether WTP in heritage tourism development is differentiated among individuals with diverse profile and backgrounds. To do so, we ran a series of nonparametric tests to illuminate any such behavioural differences based on personal traits. The results are exhibited in Table 1.

\section{[TABLE 1 SOMEWHERE HERE]}

In particular, we observe that there is a significant variance between male and female respondents, with women being more willing to participate than men. However, neither age nor the custody of underage children seems to influence WTP in our sample. In contrast, WTP varies with the level 
of education, with highly educated individuals (i.e. those holding a diploma or university degree) being significantly more willing to participate compared to all other groups. We also observe that those whose education relates to heritage and/or tourism show greater W'TP compared to those with no relevant education. Thus, there is evidence that learnt resources differentiate preferences with regard to participation in heritage tourism planning.

As far as employment is concerned, our results indicate that those expressing the highest WTP are students, part-time employees and those at retirement, implying some connection with time resources. Further, unemployed show low WTP compared to other employment statuses, which in this case might relate to limited financial resources or psychological factors. It is also interesting to note that those whose employment relates to tourism show significantly more willingness compared to individuals in other occupations. This finding is not surprising as tourism-based professionals have higher stakes in heritage tourism. We would expect a similar differentiation for those who are employed by the heritage sector; however, variation between heritage specialists and non-specialists in relation to WTP is insignificant.

In addition, our results indicate that household income does not differentiate WTP significantly. The same holds for place of origin (Kastoria or not), mode of stay at the destination (permanent or temporary) and type of residence (traditional/listed building or conventional accommodation). However, when we consider the specific location within Kastoria to which respondents relate, we observe those at places of higher heritage tourisminterest are significantly more willing to participate than those at more remote places. Such differentiation might stem fromhigher tourism stakes and/or higher attachment to local heritage.

Interestingly, WTP exhibits a U-shaped relationship with duration of stay, as those who had spent 
too little (less than five years) and too much time (more than 20 years) at Kastoria are the most willing to participate. Based on previous work, it is plausible to suggest that more experience with a place increases attachment while enhancing both the functional and affective bonds that individuals develop with a destination (Gross \& Brown, 2006). On the other hand, being new in a city may create a desire to create such bonds. It should be also noted that respondents who are currently members of local community groups/associations or who are formally or informally involved in collective activities that promote heritage show a positive differentiation in favour of WTP. This indicates that community groups and current structures of collective action can create a fertile ground for engaging with communities.

\section{Factor analysis}

Although descriptive data are informative, we need to further explore the relationship between respondents' perceptions, attitudes and their behaviour towards future participation in heritage tourism planning. To this end, we perform an exploratory principal components factor analysis with varimax rotation in order to reduce attitudinal statements on heritage values, tourism and community perceptions into a smaller set of component variables that gather similar information (Dillon et al., 2014; Lwoga, 2016; Yung \& Chan, 2012). The Kaiser-Meyer-Olkin (KMO) measure of sampling adequacy and the Bartlett's Test of Sphericity (BTS) are employed to test intercorrelations between statements. The reduced variables will then be used as predictors of WTP in heritage tourism planning (Table 2).

[TABLE 2 SOMEWHERE HERE]

In particular, our factor analysis extracts 12 component factors that make conceptual sense and have reasonably high coefficients (KMO degree of common variance is higher than 0.8 , whereas 
BTS level of significance is $\mathrm{p}=0.000$ ) (Table 3). For brevity, factor loadings are not presented here, but are available upon request.

\section{[TABLE 3 SOMEWHERE HERE]}

\section{Heritage factors}

The first heritage factor component (HER1) reflects what Mason (2002) defines as bequest values. It consists of statements that refer to the ethical need and the moral intergenerational duty to preserve and protect local heritage, expressed in a generalized/neutral way (e.g. 'it is important to protect' or 'it is beneficial to conserve'). On the other hand, the second component variable (HER2) has a more personal tone and refers to the social associations made with local heritage, such as the witnessing of place history or the emotional appeals to shared identity and sense of community. Thus, HER2 embraces qualities that more commonly relate to collective identity and sense of place, resembling what Worthing and Bond (2007) describe as associational values.

Our third heritage values factor (HER3) reflects proximity and inclusion values, comprising statements that relate to the historic districts of Kastoria and access to specific heritage sites within itshistoric core. Interestingly, the forth factor component (HER4) consists of statements that question heritage conservation and emphasize resistance to the past and a need to modernize. However, for the sake of analysis and homogeneity with other factors, we converted connotations from negative to positive and termed this factor as resistance to change. The final heritage component (HER5) was labelled as instrumental values as it concerns current and potential uses of heritage (i.e. educational, tourism) that serve contemporary purposes (e.g. transforming traditional residencies into visitors accommodation). 


\section{Tourism factors}

From our tourism components, the first (TOUR1) was labelled as high positive effects. This consists of statements that express positive attitudes towards the development of local heritage tourism services, their potential for generating both socio-cultural (e.g. incentivizing protection, promoting heritage knowledge) and socio-economic gains (e.g. stimulating the local economy, improving infrastructure) and their support for setting heritage tourism as a priority for policymaking. In contrast, statements that imply perceptions of tourism as a threat shape the second component (TOUR2).

More specifically, TOUR2 makes reference to potential negative tourism impacts, such as minimizing authenticity or causing undesirable change. For the purpose of homogeneity across statement variables, we converted negative to positive responses and labelled this factor low negative effects, reflecting a low appreciation of potential tourism costs. In a similar way, the third tourism component (TOUR3) comprises statements that refer to opportunity costs of investing in heritage tourism, question the potential of local heritage to compete with other destinations and express scepticism that heritage tourism would stimulate local development. Again, for the analysis, we converted these negative statements into positive ones so that this component variable can reflect high expectations of tourism-led development opportunities.

\section{Community-related factors}

Finally, four factor components were extracted by community-related variables that mirror respondents' mentality, political culture and perceptions of participation impact on policy. The first component variable (COM1) was coined gains of participation as it consists of general statements that validate the value of community participatory processes and its benefits for the sustainable development of local heritage tourism (e.g. safeguarding social equity, contributing to 
expert work) and the community itself (e.g. reinforcing social ties, helping participants to gain experience).

In turn, the second component (COM2) describes altruism and attachment, reflecting personal connections to locality, pro-social and pro-heritage feelings of respondents, such as prioritizing common interests over individual pursuits and investing public funds to heritage. On the other hand, the third component (COM3) consists of statements that voice pessimistic feelings of the outcomes of participation due to conflict and policy-makers' lack of true will for a meaningful

change. As previously, we reverted response values from negative to positive with COM3 expressing optimism towards conflict resolution and change. Our final component (COM4) is described as community responsibility and ties, as its statements evaluate community's role as custodian of local heritage

and community solidarity.

\section{Regression model}

Since motivations to be involved in heritage tourism governance are rather complex and shaped by multiple elements, the application of a regression analysis is an appropriate technique for identifying and quantifying the factors that determine respondents' WTP in heritage tourism planning. In particular, as we are interested in exploring the drivers that influence community attitudes towards participation, we perform a binary logistic regression analysis based on survey responses data where WTP is set as the dependent variable and heritage values, tourism perceptions and community component factors are used as predictors to respondents' behaviour. Our regression model is shown in Equation (1):

$$
W T P_{j}=a+\beta_{i} \boldsymbol{H E} \boldsymbol{R}_{j}+\gamma_{i} \boldsymbol{T O U R} j+\delta_{i} \boldsymbol{C O M}+e_{j}
$$


where $W T P_{j}$ denotes willingness to participate of respondent $j, \boldsymbol{H E} \boldsymbol{R}_{j}, \boldsymbol{T} \boldsymbol{O} \boldsymbol{U} \boldsymbol{R}_{j}$ and $\boldsymbol{C O} \boldsymbol{M}_{j}$ are the vectors of subject's $j$ attitudes towards heritage, tourism and community, and $\beta_{i}, \gamma_{i}$ and $\delta_{i}$ are the coefficients to be estimated. Finally, $e_{j}$ denotes the error term.

To test the stability of our model we first ran the regressions with a single category of component variables (either HER, or TOUR or COM) and then added them together in the equation. Results for the full sample are presented in Table 4.

\section{[TABLE 4 SOMEWHERE HERE]}

Furthermore, as demonstrated in the previous section, although host communities share some common characteristics and interests, they still exhibit certain heterogeneity, especially with regard to their personal circumstances and demographic backgrounds. Based on our earlier findings (Table 1), it is meaningful to compare behaviour among different demographic sub-groups by repeating our regression analysis with the view to explore whether our component factors (i.e. HER, TOUR, COM) alter their significance or influence on WTP. Table 5 exhibits all results whereas the rest of our analysis highlights some of the most interesting findings.

\section{[TABLE 5 SOMEWHERE HERE]}

The next sections present the empirical results and discuss their interpretation.

\section{Drivers of participation across full sample}

\section{Heritage factors}

Starting with the full sample results of Table 4, we observe that only two heritage factors exercise a significant impact on WTP. In particular, we find that collective identity and sense of place 
(HER2) has a negative effect on WTP in heritage tourism development, whereas proximity and inclusion (HER3) has a positive impact. Nonetheless, the full sample results may mask differences among the various sub-groups, given their heterogeneity, as identified in Table 1.

Thus, from Table 5, we observe that bequest values (HER1), which appear to be insignificant in the full sample, exert important influences to various sub-groups of respondents. For instance, we find that those with relevant education are influenced positively by this factor, whereas the reverse holds for respondents without such educational background. Further, bequest values demotivate WTP for those whose employment does not relate to tourism and those who belong to community groups.

Analogous dichotomies are evident for identity and sense of place (HER2), which is found negative in the full sample estimation. When we run the model with respondents' classifications that measure place attachment (i.e. location and length of stay), we find that the impact of these values is significant only for those who are located close to places of high heritage tourism interest and for those who had lived in the area for more than two decades. Likewise, proximity and inclusion (HER3) values have generally a positive effect on community but exert no influence on respondents from distant locations and those who had lived less than five years in the area.

Some interesting results are also reported for the remaining heritage factors. A notable example is resistance to change (HER4), which affects negatively those who are currently involved in community organizations and positively those not involved. We further observe that resistance to change has a positive impact on respondents with junior high education, who are also significantly influenced by instrumental values (HER5) but in a negative manner. Such relationships might express a conservative attitude towards the 're-invention' of heritage for tourism purposes. 


\section{Tourism factors}

Perhaps surprisingly but based on the full sample results we observe that expectations of tourism development do not influence WTP at a significant degree (see Table 4).

From the disaggregated analysis (see Table 5), though, we find important influences by TOUR1 and TOUR2 on the WTP of various subsample groups. In particular, it is reported that the acknowledgement of high positive tourism effects (TOUR1) impacts WTP negatively for subsamples at lowest education levels and those facing job insecurity (i.e. part-time employees and unemployed). Further, optimism with regard to tourism costs (TOUR2) demotivates participation for the less educated, for those with much experience with the place (i.e. more than 20 years) and most surprisingly, for those whose employment relates to tourism. These findings might imply a low degree of confidence, which stems from respondents' learnt resources (low educated), a sense of alienation from ripping tourism benefits (e.g. tackling unemployment) or some form of responsibility assignment towards other stakeholders (e.g. government bodies) for the planning of heritage tourism, instead of direct involvement.

\section{Community-related factors}

Finally, the full sample estimation suggests that community variables seem to be the most important drivers, with three out of the four components having a significant positive effect on our dependent variable (see Table 4). These are expected gains of participation (COM1), altruism and attachment (COM2) to community and place, and optimism towards conflict resolution and meaningful change (COM3) as the result of collaborative planning.

Nevertheless, some notable variations are identified across our subsamples (see Table 5). More specifically, high expectations of participation gains (COM1) and optimism towards conflict resolution and change (COM3) act as barriers toWTP for those with education relevant to tourism 
and/or heritage, contrary to the full sample estimation. This inverse effect on intentions to collaborate might indicate that heritage and tourism experts still feel sceptical towards community participation outcomes. Further, attitudes towards responsibility and ties (COM4) - insignificant in the full sample - incentivize participation for several clusters of respondents, including those residing near to heritage tourism places, those with longest residency, and members of communityled associations, namely for groups on which community ideals are expected to exert a greater influence.

\section{Discussion}

The empirical findings of this study display much diversity which emphasizes the heterogeneous nature of communities themselves, whose fluid and multifaceted character is shaped by interacting sociological, geographical, psychological and political elements (Cole, 2006). For instance, we observe an effect of gender on WTP with women being more willing to participate than men. A gender variation with regard to communal activity could relate to personal preferences, such as women's highest appreciation of connection and collective good values (Browne, 1995).

Further, the positive effect of education on participation identified here is also reported by previous work (e.g. Alesina \& La Ferrara, 2002; Brodie et al., 2011; Forret \& Dougherty, 2004; Frank \& Smith, 2000). Similarly, the effect of employment status on participatory behaviour, i.e. the expression of highest WTP by students, part-time employees and pensioners, lends support to the literature and its emphasis on available time as a catalyst for participatory work (Brodie et al., 2011; Holmes \& Slater, 2012). Reversely, time constraints could justify the low willingness on behalf of houseworkers due to family commitments (Alesina \& La Ferrara, 2002; Holmes \& Slater, 2012) but are less relevant to the unemployed, who have also little desire to be involved in heritage tourism planning. Psychological factors relating to unsuccessful professional experiences (Alesina 
\& La Ferrara, 2002) or a lack of practical resources (Brodie et al., 2011) might discourage the latter from taking on a more active role in their community.

In addition, the relationship between W'TP and location, which indirectly relates to high or low tourism stakes, is also not surprising. The literature suggests that community attitudes can be influenced by their proximity to heritage tourism locations (Sharma \& Dyer, 2009), as their everyday lives and access to heritage are more likely to be interrupted by tourism development. Thus, the geographical element of proximity or distance is in fact a significant factor that alters community behaviour towards participation progressively.

In contrast, felt proximity/distance and connection with the place, measured by length of residence, appears to be more complicated with regard to participation intentions, as the relationship is non-linear. Rather, highest willingness is exhibited by the two extremes - those with relatively little or too much acquaintance with the place, with a 'gap' in-between them. Earlier studies have found that place attachment by itself does not increase social participation (Hays \& Kogl, 2007; Wu, 2012), whereas, WTP might be 'overshadowed' by other socio-political circumstances, which are difficult to capture here.

Interestingly, when we focus on the attitudinal factors that shape WTP, the aforementioned groups exhibit more commonalities than differences. In particular, almost all groups are primarily driven by community factors, which reflect either purposive (COM1) or solidary (COM2) motivations (Caldwell \& Andereck, 1994). The effect of these factors is weaker only for respondents with low place attachment (i.e. $<5$ years length of stay) and for those with heritage-tourism education. In fact, the latter are incentivized predominantly by bequest values (HER1), confirming the influence of Smith's (2006) 'authorized heritage discourse' and its notion that heritage experts are the custodians of the past and those who should pass it on to future generations. In contrast, as 
reported by Mydland and Grahn (2012), local communities are mobilized to safeguard heritage less by bequest values and more by a desire to reinforce social ties and common social institutions.

Similarly, barriers to participation are of equal interest as many key sub-groups (e.g. highly educated, fully employed, residents of key tourism areas, respondents with high place attachment, members of local cultural associations) appear to be mostly discouraged by heritage values that relate to identity and sense of place (HER2). Such a negative relation might stem from a perceived threat of community displacement by visitors and tourism businesses that would disrupt or transform the character of the place, its heritage landscapes and everyday life (Suntikul \& Jachna, 2013).

Overall, based on our earlier hypotheses, we find that heritage values can play both a positive and a negative role in community intentions to participate. Alterations depend both on the type of values (e.g. inclusion values drive WTP positively whereas place identity values exert a negative effect) and on the particular community group they concern (e.g. bequest values drive only those who have certain heritage expertise whereas inclusion values are irrelevant for those with low place attachment). Thus, H1 can be marginally accepted, as there are also heritage values that exert inverse effects on intentions to participate in heritage tourism planning. In parallel, tourism perceptions, especially for communities that have witnessed limited tourism growth, have mostly insignificant effects on WTP. Based on such results, H2 is rejected. Rather, participation is largely driven by community ideals, and this is particularly evident for community members with high place attachment (e.g. proximity, length of stay, current involvement in collective activities). Therefore, our testable hypothesis $\mathrm{H} 3$ can be accepted.

\section{Conclusion}

Recent years witnessed an increased interest in heritage tourism and community participation in 
its planning and management; however, our hands-on knowledge of engaging with communities is still fragmented while research on community drivers for participating is limited. In view of this, this paper endeavoured to shed light into the attitudinal and practical factors that might influence community intentions towards participation. Using the case study of Kastoria, Greece, and an attitudinal survey instrument, the study collected and analysed community responses in order to disentangle the influence of heritage values, expected tourism impacts and community-related factors on WTP in the design of heritage tourism at their destination. The findings of the research not only inform policy approaches to meaningful participation but they also advance our theoretical understanding of community aspirations and motivations to personally invest in such collaborations.

Our data provide empirical evidence that largely supports the literature while illuminating some interesting variations among different community fractions. In particular, community ideals seem to play the most pivotal role in driving intentions towards involvement. Expected gains of participation, altruism and emotional attachment to the destination, along with optimism towards conflict resolution and a meaningful change from collaborative planning act as positive drivers to respondents' WTP. Contrary to our initial hypothesis, a high assignment of values to cultural heritage plays both a positive and a negative role in participation intensions. This suggests that tourism might be partly viewed as antagonistic to heritage in terms of leading to a clash between protection and commercial opportunities (Wang \& Bramwell, 2012) or by causing community displacement and the disruption of heritage landscapes (Suntikul \& Jachna, 2013). As far as tourism-led benefits and development expectations are concerned, their influence on WTP is mainly insignificant. Rather, personal circumstances, such as learnt resources, time, job security, physical and psychological proximity to heritage places were found to differentiate WTP considerably. 
Based on these findings, some important implications can be highlighted. First, community-led collaborations for the planning of heritage tourism need to be founded primarily on community values. Given that previous research suggests that the reinforcement of common social institutions mobilizes heritage preservation by local communities (Mydland \& Grahn, 2012), the contribution of participation towards such goal needs to be emphasized and promoted. A higher WTP on behalf of those currently involved in grassroots activity (e.g. through cultural associations) indicates that existing structures of collective action can serve as a starting point for engaging with stakeholders who are excluded by conventional top-down planning.

Second, given that tourism might be understood as a threat to heritage and place identity, it is important for communication and engagement strategies to convincingly highlight the criticality of collaborative planning for preventing undesirable tourism change. This presupposes a commitment of contribution to the development of indicators that will empower the host community to make choices in accordance to its cultural values and capacity. Third, the fact that tourism factors are found insignificant in incentivizing the community might illustrate a weak link between tourism gains and their perceived potential socio-economic spillovers. Therefore, policymaking needs to convincingly build a development path towards broader socio-economic gains to avoid tokenistic or short-lived involvement.

Overall, the results of our study highlight the importance of considering the ideological and practical needs of potential community participants before moving on to the participatory process per se. Although time-consuming, this process could prove vital for building solid communication and engagement strategies and realizing the benefits of collaborative decision-making. Our proposition is that in order to be inclusive and accessible, participatory projects need to develop organically, based on values that are locally relevant, and practices adapted to serve these values. 
Obviously, these findings are based on a single case study of a particular place and time. Future research could expand this enquiry to other destinations and compare communities across different places or phases of tourism growth, as incentives to participate are likely to change their character and magnitude over time. In addition, alternative methodological approaches could further disentangle the contextual relationships of the factors explored here. For instance, given that survey tools are limited by their setting in a hypothetical context (e.g. intentions to participate might not necessarily translate into real commitments in the future), experimental and behavioural methodologies could greatly complement this area of research and help us further illuminate the interplay of drivers and barriers to participation.

\section{References}

Aas, C., Ladkin, A., \& Fletcher, J. (2005). Stakeholder collaboration and heritage management. Annals of Tourism Research, 32(1), 28-48.

Alesina, A., \& La Ferrara, E. (2002). Who trusts others? Journal of Public Economics, 85(2), 207234.

Andereck, K. L., Valentine, K. M., Knopf, R. C., \& Vogt, C. A. (2005). Residents' perceptions of community tourism impacts. Annals of Tourism Research, 32(4), 1056-1076.

Ashley, K. S., Osmani, M., Emmitt, S., Mallinson, M., \& Mallinson, H. (2015). Assessing stakeholders' perspectives towards the conservation of the built heritage of Suakin, Sudan. International Journal of Heritage Studies, 21(7), 674-697.

Atalay, S. (2010). 'We don't talk about Catalhoyuk, we live it': Sustainable archaeological practice through community-based participatory research. World Archaeology, 42(3), 418-429.

Bernard, H. R. (2011). Research methods in anthropology: Qualitative and quantitative approaches (5th ed). Lanham, MD: Altamira Press.

Bessiere, J. (2013). 'Heritagisation', a challenge for tourism promotion and regional development: An example of food heritage. Journal of Heritage Tourism, 8(4), 275-291.

Brodie, E., Hughes, T., Jochum, V., Miller, S., Ockenden, N., \& Warburton, D. (2011). Pathways through participation. London: NCVO, Involve, IVR.

Browne, C. V. (1995). Empowerment in social work practice with older women. Social Work, 40(3), 358-364.

Byrd, E. T., Bosley, H. E., \& Dronberger, M. G. (2009). Comparisons of stakeholder perceptions of tourism impacts in rural eastern North Carolina. Tourism Management, 30, 693-703.

Caldwell, L. L., \& Andereck, K. L. (1994). Motives for initiating and continuing membership in a recreation-related voluntary association. Leisure Sciences, 16(1), 33-44.

Cohen-Hattab, K. (2013). Public involvement and tourism planning in a historic city: The case of the old city of Jerusalem. Journal of Heritage Tourism, 8(4), 320-336. 
Cole, S. (2006). Cultural tourism, community participation and empowerment. In M. K. Smith \& M. Robinson (Eds.), Cultural tourism in a changing world: Politics, participation and (re) presentation (pp. 89-103). Clevedon: Channel View.

Council of Europe Development Bank. (2015, April). Restoration and rehabilitation of Kastoria's Dolcho and Apozari neighbourhoods. Pedro Ponce de León.

Currie, R. R., Seaton, S., \& Wesley, F. (2009). Determining stakeholders for feasibility analysis. Annals of Tourism Research, 36(1), 41-63.

de la Torre, M. (2013). Values and heritage conservation. Heritage \& Society, 6(2), 155-166.

Dillon, C., Bell, N., Fouseki, K., Laurenson, P., Thompson, A., \& Strlič, M. (2014). Mind the gap: Rigour and relevance in collaborative heritage science research. Heritage Science, 2(1), 1-22.

Dines, N. (2016). An irreconcilable first-place: The precarious life of tourism and heritage in a southern European historic centre. International Journal of Heritage Studies. doi:10.1080/13527258.2016.1195428.

Dodds, R. (2007). Sustainable tourism and policy implementation: Lessons from the case of Calvia, Spain. Current Issues in Tourism, 10(4), 296-322.

Fan, L. (2014). International influence and local response: Understanding community involvement in urban heritage conservation in China. International Journal of Heritage Studies, 20(6), 651662.

Forret, M. L., \& Dougherty, T. W. (2004). Networking behaviors and career outcomes: Differences for men and women? Journal of Organizational Behavior, 25(3), 419-437.

Fouseki, K., \& Sakka, N. (2013). Valuing an ancient Palaestra in the centre of Athens: The public, the experts, and Aristotle. Conservation and Management of Archaeological Sites, 15(1), 3044.

Frank, F., \& Smith, A. (2000). The partnership handbook. Ottawa: Minister of Public Works and Government Services Canada.

Giachello, A. L. (2007). Making community partnerships work: A toolkit. New York, NY: March of Dimes Foundation.

Gross, M. J., \& Brown, G. (2006). Tourism experiences in a lifestyle destination setting: The roles of involvement and place attachment. Journal of Business Research, 59(6), 696-700.

Hall, C. M. (2007). Tourism planning: Policies, processes and relationships (2nd ed.). Harlow: Prentice Hall.

Hays, R. A., \& Kogl, A. M. (2007). Neighborhood attachment, social capital building, and political participation: A case study of low- and moderate-income residents of waterloo, Iowa. Journal of Urban Affairs, 29(2), 181-205.

Hellenic Statistical Authority. (2011). Resident population census. Retrieved from http://www.statistics.gr/2011-censuspop-hous [in Greek]

Hellenic Statistical Authority. (2016). Greece in figures: January-March 2016. Retrieved from http://www.statistics.gr/documents/20181/1515741/GreeceInFigures_2016Q1_GR.pdf [in Greek]

Holmes, K., \& Slater, A. (2012). Patterns of voluntary participation in membership associations a study of UK heritage supporter groups. Nonprofit and Voluntary Sector Quarterly, 41(5), 850 869.

Johnston, R. J., \& Tyrrell, T. J. (2008). Sustainability and tourism dynamics. In A. G. Woodside \& D. Martin (Eds.), Tourism management: Analysis, behaviour and strategy (pp. 470-492). Wallingford: CABI. 
Kimbu, A. N., \& Ngoasong, M. Z. (2013). Centralised decentralisation of tourism development: A network perspective. Annals of Tourism Research, 40, 235-259.

Krejcie, R. V., \& Morgan, D. W. (1970). Determining sample size for research activities. Educational and Psychological Measurement, 30, 607-610.

Landorf, C. (2009). A framework for sustainable heritage management: A study of UK industrial heritage sites. International Journal of Heritage Studies, 15(6), 494-510.

Li, Y., \& Hunter, C. (2015). Community involvement for sustainable heritage tourism: A conceptual model. Journal of Cultural Heritage Management and Sustainable Development, 5(3), 248-262.

Lwoga, N. B. (2016). Factors influencing local residents' intentions to conserve the built heritage in Tanzania. Journal of Heritage Tourism. doi:10.1080/1743873X.2016.1213846

Marzuki, A., Hay, I., \& James, J. (2012). Public participation shortcomings in tourism planning: The case of the Langkawi Islands, Malaysia. Journal of Sustainable Tourism, 20(4), 585-602.

Mason, R. (2002). Assessing values in conserving planning: Methodological issues and choices. In M. de la Torre (Ed.), Assessing the values of cultural heritage (pp. 5-30). Los Angeles, CA: The Getty Conservation Institute.

Mason, R. (2006). Theoretical and practical arguments for values-centered preservation. CRM: The Journal of Heritage Stewardship, 3, 21-48.

McClelland, A., Peel, D., Hayes, C. M., \& Montgomery, I. (2013). A values-based approach to heritage planning: Raising awareness of the dark side of destruction and conservation. Town Planning Review, 84(5), 583-604.

Mydland, L., \& Grahn, W. (2012). Identifying heritage values in local communities. International Journal of Heritage Studies, 18(6), 564-587.

Nunkoo, R., \& Ramkissoon, H. (2011). Developing a community support model for tourism. Annals of Tourism Research, 38(3), 964-988.

Okazaki, E. (2008). A community-based tourism model: Its conception and use. Journal of Sustainable Tourism, 16(5), 511-529.

Oppenheim, A. N. (2001). Questionnaire design: Interviewing and attitude measurement (6th ed.). London: Continuum.

Pacifico, D., \& Vogel, M. (2012). Archaeological sites, modern communities, and tourism. Annals of Tourism Research, 39(3), 1588-1611.

Perkin, C. (2010). Beyond the rhetoric: Negotiating the politics and realising the potential of community-driven heritage engagement. International Journal of Heritage Studies, 16(1-2), 107-122.

Reid, D. G., Mair, H., \& George, W. (2004). Community tourism planning: A self-assessment instrument. Annals of Tourism Research, 31(3), 623-639.

Sharma, B., \& Dyer, P. (2009). Residents' involvement in tourism and their perceptions of tourism impacts. Benchmarking: An International Journal, 16(3), 351-371.

Simpson, M. C. (2008). Community benefit tourism initiatives - A conceptual oxymoron? Tourism Management, 29(1), 1-18.

Smith, L. (2006). Uses of heritage. Oxford: Routledge.

Smith, L. (2009a). Deference and humility: The social values of the country house. In L. Gibson \& J. Pendlebury (Eds.), Valuing historic environments (pp. 33-50). Farnham: Ashgate.

Smith, M. (2009b). Issues in cultural tourism (2nd ed.). London: Routledge. 
Sofield, T. H. B. (2003). Empowerment for sustainable tourism development. Oxford: Pergamon, Elsevier Science.

Stephens, J., \& Tiwari, R. (2015). Symbolic estates: Community identity and empowerment through heritage. International Journal of Heritage Studies, 21(1), 99-114.

Su, M. M., \& Wall, G. (2014). Community participation in tourism at a world heritage site: Mutianyu Great Wall, Beijing, China. International Journal of Tourism Research, 16(2), 146156.

Suchet, A., \& Raspaud, M. (2010). A case of local rejection of a heritage tourism policy: Tourism and dynamics of change in Abondance, French Alps. International Journal of Heritage Studies, 16(6), 449-463.

Suntikul, W., \& Jachna, T. (2013). Contestation and negotiation of heritage conservation in Luang Prabang, Laos. Tourism Management, 38, 57-68.

Svensson, E. (2015). Heritage and development outside the metropolis: Discussing issues of attractiveness, growth, participation and sustainable development. Journal of Cultural Heritage Management and Sustainable Development, 5(1), 4-13.

Timothy, D. J., \& Nyaupane, G. P. (2009). Heritage tourism and the less developed world. In D. J. Timothy \& G. P. Nyaupane (Eds.), Cultural heritage and tourism in the developing world: A regional perspective (pp. 3-19). London: Routledge.

United Nations Educational, Scientific and Cultural Organization. (2012). Convention concerning the protection of the world cultural and natural heritage: World Heritage Tourism Programme (WHC-12/36.COM/5E).

United Nations World Tourism Organization. (2008). Sustainable tourism indicators and destination management.

Waligo, V. M., Clarke, J., \& Hawkins, R. (2013). Implementing sustainable tourism: A multistakeholder involvement management framework. Tourism Management, 36, 342-353.

Wall, G., \& Mathieson, A. (2006). Tourism: change, impacts, and opportunities. New York: Pearson Education.

Walter, N. (2014). From values to narrative: A new foundation for the conservation of historic buildings. International Journal of Heritage Studies, 20(6), 634-650.

Wang, Y., \& Bramwell, B. (2012). Heritage protection and tourism development priorities in Hangzhou, China: A political economy and governance perspective. Tourism Management, 33(4), 988-998.

Worthing, D., \& Bond, S. (2007). Managing built heritage: The role of cultural significance. London: Wiley-Blackwell.

Wu, F. (2012). Neighborhood attachment, social participation, and willingness to stay in China's low-income communities. Urban Affairs Review, XX(X), 1-24.

Wu, T. C. E., Xie, P. F., \& Tsai, M. C. (2015). Perceptions of attractiveness for salt heritage tourism: A tourist perspective. Tourism Management, 51, 201-209.

Yung, H. K. E., \& Chan, H. W. E. (2012). Critical social sustainability factors in urban conservation: The case of the central police station compound in Hong Kong. Facilities, 30(9/10), 396-416. 
Figure 1 Elements that may affect community's W'TP in heritage tourism.

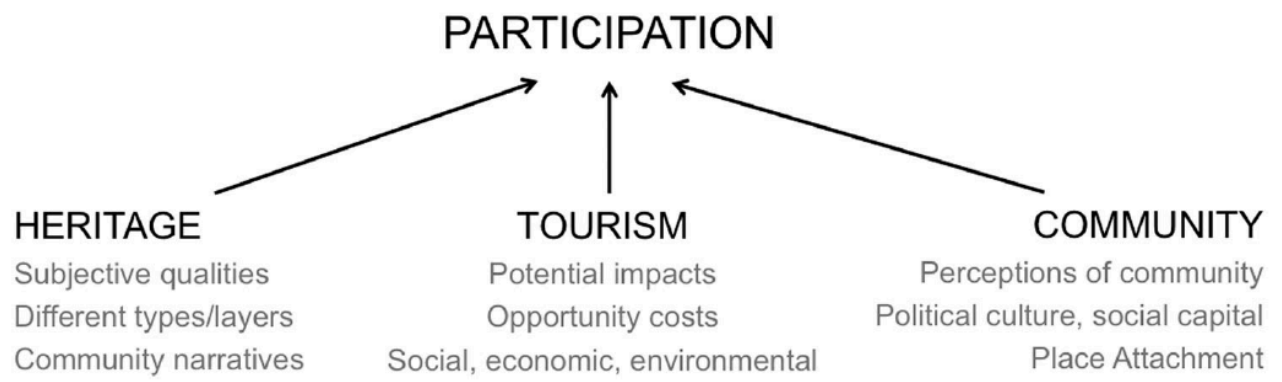

Table 1. Demographic characteristics and their influence on WTP.

\begin{tabular}{|c|c|c|}
\hline Variable & Clusters & $\begin{array}{l}\text { Test } \\
\text { statistic }\end{array}$ \\
\hline Gender & Males/Females & $-2.129^{* *, a}$ \\
\hline Age & $18-24 ; 25-34 ; 35-44 ; 45-54 ; 55-64 ; 65+$ & $3.297^{\mathrm{b}}$ \\
\hline Underage Children & Yes/No & $-1.378^{\mathrm{a}}$ \\
\hline General education & $\begin{array}{l}\text { Ir high diploma or lower; High school diploma; Technical Diploma; Graduate } \\
\text { degree; Post-Graduate degree }\end{array}$ & $32.203^{* * *, \mathrm{~b}}$ \\
\hline Relevant education & Yes/No & $-3.141^{* * a}$ \\
\hline Employment status & $\begin{array}{l}\text { Unemployed; Student; Full-time employee; Part-time employee; Family/ } \\
\text { housework; Retired }\end{array}$ & $18.018^{* *, \mathrm{~b}}$ \\
\hline Heritage-related employment & Yes/No & $-0.822^{\mathrm{a}}$ \\
\hline Tourism-related employment & Yes/No & $-3.222^{* * * a}$ \\
\hline Household income & $<\epsilon 5,000 ;<\epsilon 10,000 ;<\epsilon 20,000 ;<\epsilon 30,000 ;>\epsilon 30,000$ (annually) & $4.897^{\mathrm{b}}$ \\
\hline Place of birth & Kastoria/elsewhere & $-0.127^{\mathrm{a}}$ \\
\hline Place of residence & Kastoria/elsewhere & $-0.545^{\mathrm{a}}$ \\
\hline Type of residence & Traditional or listed building/conventional accommodation & $-0.303^{\mathrm{a}}$ \\
\hline Specific area of residence/work & $\begin{array}{l}\text { Outside Kastoria; Historic centre; New city neighbourhoods; Towns-villages close } \\
\text { to key heritage sites; Towns-villages remote to key heritage sites }\end{array}$ & $13.719^{* * *, b}$ \\
\hline Duration of stay & $<1 \mathrm{yr} ;<5 \mathrm{yrs} ;<10 \mathrm{yrs} ;<20 \mathrm{yrs} ; 5:>20 \mathrm{yrs}$ & $8.505^{*, \mathrm{~b}}$ \\
\hline $\begin{array}{l}\text { Membership to community } \\
\text { groups/associations }\end{array}$ & Yes/No & $-4.562^{* * * a}$ \\
\hline $\begin{array}{l}\text { Formal/informal involvement in } \\
\text { promoting heritage }\end{array}$ & Yes/No & $-9.983^{* * *, a}$ \\
\hline
\end{tabular}


Table 2. Factor components reflecting attitudes towards heritage, tourism and community.

Heritage values (HER)

HER1: Bequest value Statements that refer to the ethical need and the intergenerational duty to study and protect local heritage.
HER2: Identity/sense of place
Statements expressing personal, social and affective associations with local heritage.
HER3: Proximity/ Inclusion
Statements that relate to the historic districts of Kastoria and access to specific heritage sites within its historic core.
Kastoria is rich in archaeological remains that deserve scientific research.

- Archaeological excavations conducted in the area are beneficial as they reveal the history of the place.

- The Byzantine monuments of Kastoria are of international cultural significance and we need to protect them and promote them.

- The Byzantine and post-Byzantine artwork of Kastoria is of unique artistic value.

- The traditional architecture of Kastoria reflects the hard-working, creativity and culture of the place.

- It is important to protect cultural heritage so that we can bequest it to our next generations.

- The fur art and traditional craftsmanship is part of the common cultural identity of Kastorians.

- The mud brick houses in the abandoned villages of Kastoria witness place history and shared memory from civil war.

- Traditional customs, such as the local carnival, provide opportunities for community gatherings and collective identity making.

- The most beautiful parts of the city are its old traditional neighbourhoods (Dolcho and Apozari).

- The area surrounding Koubelidiki church (historic centre) should be protected from any aesthetic damage.

- The demolition of the old traditional high school in the historic centre was a huge mistake due to its historic value.

- It is important to open the Tsiatsiapa Mansion (historic centre) to the local community once conservation works are complete.

- We need to protect the Ottoman monuments of Kastoria as they form part of the history of the place.

- In their majority, traditional or neoclassical houses are more beautiful than contemporary ones.

- The image of Kastoria would have been worse if it had less listed/preserved buildings.

- The Ottoman barracks should not be demolished for the erection of the new police station.

- It is important to have educational activities that relate to archaeological and heritage work at Kastoria.

- The re-use of listed buildings as hotels and restaurants made Kastoria more attractive to visitors.

Perceptions of tourism (TOUR)

TOUR1: High positive Statements that express positive attitudes towards - Tourism development should be a priority in the effects the development of the local heritage tourism local govemment agenda. 
Table 2. Continued goal.
TOUR2: Low negative effects ${ }^{\mathrm{a}}$
Statements reflecting a low appreciation of potential tourism costs.
TOUR3:

Development opportunities
Statements that refer to heritage tourism as a development opportunity for the area. to cultural heritage.

- The linking of tourism with heritage in Kastoria will create incentives for the protection and promotion of local cultural heritage.

- The development of heritage tourism will contribute to the development of the local economy.

- The development of heritage tourism will provide incentives to the local community to learn more about their cultural heritage.

- Tourism development will lead to infrastructure and services development for the local community.

- An increase of visitor numbers will not be detrimental to the authenticity of the local Carnival and other traditional customs.

- Tourism development in Kastoria will not lead to the degradation of its urban environment.

- The increase of tourism in Kastoria will not lead to the degradation of the natural environment.

- Despite not being a seaside destination, Kastoria has high potential for tourism development.

- Heritage tourism is one of the best solutions for Kastoria compared to other development options.

- Tourism development will contribute to unemployment reduction.

- Tourism can provide broader economic benefits, not only for those who engage with it directly (e.g. hoteliers, restaurant owners).

- It is important that citizens participate in the protection and promotion of cultural heritage.

- The design of heritage tourism in Kastoria should be done in cooperation with as many stakeholder groups as possible.

- Community participation in activities for the development of heritage tourism would reinforce social ties among the local community.

- Community participation in activities for the development of heritage tourism would help participants to gain skills/experience.

- Community participation in activities for the development of heritage tourism would contribute to experts' work on heritage-tourism issues.

- Community participation in activities for the development of heritage tourism would safeguard that decisions made are beneficial to everyone.

- Despite other local problems, it is worth spending public money to cultural heritage.

2: Altruism \& Statements reflecting personal attachment to attachment locality, pro-social and pro-heritage feelings.
- Community/public interests are more important than individual interests.

- I personally feel deeply connected to Kastoria.

(Continued) 
Table 2. Continued

Factor name

COM3: Conflict resolution \& change $^{\text {a }}$

Description

Attitude statements included

- I would like to help Kastoria and contribute to its development.

- Community participation in activities for the development of heritage tourism will lead to fertile results despite conflict.

Statements that voice optimistic feelings towards conflict resolution and trust.

- Community participation in activities for the development of heritage tourism can have a positive impact and overcome issues arising from the political status quo.

COM4: Responsibility Statements referring to heritage custody and \& ties community cohesion.
- Government agencies are not exclusively responsible for the protection and promotion of monuments.

- I feel that Kastorians are closely tied to each other.

${ }^{\mathrm{a} F a c t o r}$ scores were reversed for reporting results that express positive attitudes/beliefs. 
Table 3. Principal component analysis results.

\begin{tabular}{lccc}
\hline Component variables & KMO index & BTS Sig. $(p-v a l u e)^{\mathrm{b}}$ & Variance explained (\%) \\
\hline Heritage values & 0.908 & 0.000 & 54.38 \\
HER1: Bequest value & & & 32.07 \\
HER 2: Collective identity/sense of place & & & 7.89 \\
HER 3: Proximity/Inclusion & & & 5.22 \\
HER 4: Resistance to change & & & 5.00 \\
HER 5: Instrumental value & 0.842 & 0.000 & 4.20 \\
Perceptions of tourism & & & 51.50 \\
TOUR1: Tourism as a source of benefits & & & 31.16 \\
TOUR2: Tourism as (not) a source of costs & 0.823 & 0.000 & 13.20 \\
TOUR3: Development opportunities & & & 7.14 \\
Community factors & & 59.35 \\
COM1: Gains of participation & & 31.31 \\
COM2: Altruism \& attachment & & 11.36 \\
COM3: Conflict resolution \& change & & 8.65 \\
COM4: Responsibility \& ties & & 8.03 \\
\hline
\end{tabular}

${ }^{\mathrm{a}} \mathrm{KMO}$ index ranges from 0 to 1 , with anything above 0.50 to be considered suitable for factor analysis.

${ }^{\mathrm{b}} \mathrm{BTS}$ is significant when $p<.05$.

Table 4. Attitudinal factors driving WTP.

\begin{tabular}{lcccc}
\hline & WTP & WTP & WTP & WTP \\
\hline $\begin{array}{l}\text { Constant } \\
\text { Heritage values (HER) }\end{array}$ & $0.564^{* * *}$ & $0.566^{* * *}$ & $0.585^{* * *}$ & $0.610^{* * *}$ \\
$\begin{array}{l}\text { Bequest value } \\
\text { Collective identity/sense of place }\end{array}$ & $0.147^{*}$ & & & -0.155 \\
$\begin{array}{l}\text { Proximity/Inclusion } \\
\text { Resistance to change }\end{array}$ & -0.040 & & & $-0.321^{* * *}$ \\
$\begin{array}{l}\text { Instrumental value } \\
\text { Perceptions of tourism (TOUR) }\end{array}$ & $0.339^{* * *}$ & & & $0.221^{* *}$ \\
High positive effects & $0.157^{* *}$ & & 0.071 \\
Low negative effects & & & & 0.003 \\
Development opps. & & $0.139^{* *}$ & & -0.196 \\
Community factors & 0.040 & & -0.022 \\
Gains of participation & & $0.479^{* * *}$ & & 0.151 \\
Altruism \& attachment & & & $0.609^{* * *}$ \\
Conflict resolution \& change & & & $0.317^{* * *}$ & $0.678^{* * *}$ \\
Responsibility \& ties & & & $0.580^{* * *}$ & $0.254^{* * *}$ \\
R-squared & & $0.296^{* *}$ & 0.176 \\
\hline
\end{tabular}

Note: This table presents the results of Equation (1) $\left(\right.$ WTP $_{j}=a+\beta_{i} \boldsymbol{H E R}_{j}+\gamma_{i}$ TOUR $\left._{j}+\delta_{i} \boldsymbol{C O M}_{j}+e_{j}\right)$.

$*, * *,{ }^{* *}$ Significance at $10 \%, 5 \%$, and $1 \%$, respectively. 
Table 5. Attitudinal factors driving WTP based on demographic subsamples.

\begin{tabular}{|c|c|c|c|c|c|c|c|c|c|c|c|}
\hline & \multicolumn{2}{|c|}{ Tourism employment } & \multicolumn{2}{|c|}{ Location } & \multicolumn{3}{|c|}{ Duration of stay } & \multicolumn{2}{|c|}{$\begin{array}{l}\text { Membership to } \\
\text { community groups }\end{array}$} & \multicolumn{2}{|c|}{ Contribution to heritage } \\
\hline & No & Yes & Near & Distant & $0-5 y r s$ & 6-20yrs & $>20 y r s$ & No & Yes & No & Yes \\
\hline \multicolumn{12}{|l|}{ Heritage values (HER) } \\
\hline Bequest value & $-0.279^{* *}$ & 0.524 & -0.240 & 0.123 & $-2.333^{*}$ & 0.203 & $-0.482^{* * *}$ & $-0.237^{*}$ & 0.264 & -0.179 & -0.123 \\
\hline Identity/sense of place & $-0.328^{* *}$ & -0.379 & $-0.478 * * *$ & -0.048 & 0.34 & -0.125 & $-0.563^{* * *}$ & $-0.352^{* * *}$ & $-1.593^{* * *}$ & -0.231 & -0.199 \\
\hline Proximity/Inclusion & $0.254^{* *}$ & 0.258 & $0.355^{* * *}$ & 0.070 & $-1.869^{* *}$ & $0.513^{* *}$ & $0.305^{* *}$ & 0.065 & 0.618 & 0.129 & $0.506 * *$ \\
\hline Resistance to change & 0.009 & 0.410 & -0.073 & 0.229 & $-3.040^{*}$ & $0.449^{*}$ & -0.149 & $0.225 * *$ & $-1.521^{* * *}$ & -0.012 & $-0.532^{*}$ \\
\hline Instrumental value & -0.053 & 0.046 & 0.014 & 0.073 & 0.27 & 0.151 & -0.094 & 0.140 & -0.600 & 0.123 & -0.037 \\
\hline \multicolumn{12}{|l|}{ Tourism perceptions (TOUR) } \\
\hline High positive effects & -0.212 & -0.211 & -0.303 & -0.285 & $3.709 * *$ & -0.270 & -0.213 & -0.109 & -0.93 & -0.042 & $-0.772 * *$ \\
\hline Low negative effects & 0.086 & $-0.723 * *$ & 0.021 & -0.247 & $4.821^{* * *}$ & $0.417^{*}$ & $-0.220^{*}$ & 0.33 & $-0.609^{*}$ & 0.185 & $-0.516^{*}$ \\
\hline $\begin{array}{l}\text { Development opps. } \\
\text { Community factors (Сом) }\end{array}$ & $0.289^{* *}$ & -0.077 & 0.114 & 0.282 & $3.980^{* *}$ & 0.300 & 0.021 & 0.108 & 0.586 & 0.262 & -0.032 \\
\hline Gains of participation & $0.704^{* * *}$ & 0.390 & $0.924 * * *$ & $0.465^{*}$ & $-3.538^{* *}$ & 0.506 & $0.978 * * *$ & $0.474^{* * *}$ & $1.326 * * *$ & $0.331^{*}$ & $0.779 * *$ \\
\hline Altruism \& attachment & $0.715^{* * *}$ & $0.793 * *$ & $0.705^{* * *}$ & $0.556^{* * *}$ & $3.524 * *$ & 0.245 & $0.831^{* * *}$ & $0.748^{* * *}$ & $0.924 * *$ & $0.722^{* * *}$ & $0.750^{* * *}$ \\
\hline Conflict resolution \& change & 0.142 & 0.357 & $0.383^{* * *}$ & 0.180 & $2.372^{*}$ & $0.566^{* *}$ & $0.319 * * *$ & 0.87 & $0.809^{* * *}$ & 0.087 & $0.458^{* *}$ \\
\hline Responsibility \& ties & $0.210^{* *}$ & -0.021 & $0.264^{* *}$ & 0.038 & -0.070 & -0.263 & $0.356 * * *$ & 0.133 & $0.532^{*}$ & 0.198 & -0.067 \\
\hline$R$-squared & 0.234 & 0.247 & 0.235 & 0.195 & 0.760 & 0.290 & 0.252 & 0.192 & 0.595 & 0.204 & 0.279 \\
\hline
\end{tabular}

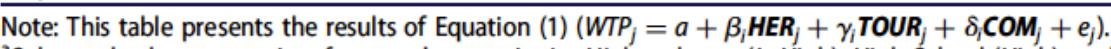

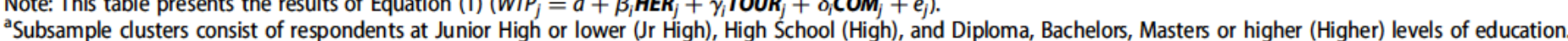

bSubsample clusters consist of respondents who are Students, Part-time employees, Retired (PT), Full-time employees (FT), Unemployed and Housewives (UN).

'Subsample clusters consist of respondents who either live in close proximity to (Near) or to remotely from (Distant) areas of high heritage tourism interest.

$* *^{* *}$, ${ }^{* *}$ Significance at $10 \%, 5 \%$, and $1 \%$, respectively. 
Table 5. Continued

\begin{tabular}{|c|c|c|c|c|c|c|c|c|c|c|}
\hline \multirow[b]{4}{*}{ Component factors } & \multicolumn{10}{|c|}{ WTP } \\
\hline & \multicolumn{10}{|c|}{ Subsamples } \\
\hline & \multicolumn{2}{|c|}{ Gender } & \multicolumn{3}{|c|}{ General education $^{a}$} & \multicolumn{2}{|c|}{ Relevant education } & \multicolumn{3}{|c|}{ Employment status $^{\mathrm{b}}$} \\
\hline & Males & Females & Jr High & High & Higher & No & Yes & PT & $\mathrm{FT}$ & UN \\
\hline $\begin{array}{l}\text { Constant } \\
\text { Heritage values (HER) }\end{array}$ & $0.558^{* * *}$ & $0.780^{* * * *}$ & 2.036 & $0.321^{* *}$ & $0.992^{* * * *}$ & $0.558^{* * *}$ & $2.166^{* * *}$ & $1.068^{* * * *}$ & $0.697^{* * *}$ & 0.326 \\
\hline Bequest value & $-0.498^{* * *}$ & 0.212 & 2.194 & -0.279 & -0.304 & $-0.309^{* *}$ & $2.208^{* * *}$ & 0.394 & $-0.555^{* * *}$ & -0.261 \\
\hline Identity/sense of place & $-0.663^{* * *}$ & -0.089 & $-6.723^{*}$ & -0.310 & $-0.732^{* * *}$ & $-0.330^{* *}$ & -0.196 & -0.129 & $-0.912^{* * *}$ & -0.073 \\
\hline Proximity/Inclusion & 0.134 & $0.293^{*}$ & 0.983 & 0.215 & $0.337^{* *}$ & $0.191^{*}$ & 0.366 & 0.205 & 0.100 & $0.519^{* *}$ \\
\hline Resistance to change & -0.021 & 0.175 & $6.699 *$ & -0.116 & 0.071 & 0.025 & 0.608 & 0.235 & -0.083 & -0.103 \\
\hline $\begin{array}{l}\text { Instrumental value } \\
\text { Tourism perceptions (TOUR) }\end{array}$ & 0.107 & -0.008 & $-2.864^{*}$ & -0.257 & 0.103 & -0.091 & $1.039^{* * *}$ & $0.451^{*}$ & -0.092 & -0.280 \\
\hline High positive effects & 0.245 & $-0.759^{* * *}$ & $-16.774^{*}$ & 0.197 & -0.321 & -0.197 & -0.380 & $-0.837^{* *}$ & 0.153 & $-0.631^{*}$ \\
\hline Low negative effects & 0.136 & -0.242 & $-14.789 * *$ & 0.015 & $0.413^{* * *}$ & -0.058 & -0.027 & -0.274 & 0.210 & -0.276 \\
\hline $\begin{array}{l}\text { Development opps. } \\
\text { Community factors (СОM) }\end{array}$ & 0.200 & 0.166 & -0.941 & 0.275 & 0.11 & 0.135 & $0.738^{*}$ & $0.532^{* *}$ & -0.076 & 0.255 \\
\hline Gains of participation & $0.435 * *$ & $0.847^{* * *}$ & $17.939^{*}$ & $0.487 * *$ & $0.898^{* * *}$ & $0.788^{* * *}$ & $-2.286^{* * *}$ & $0.869 * *$ & $0.707^{* * *}$ & $1.036^{* * *}$ \\
\hline Altruism \& attachment & $0.891^{* * *}$ & $0.521^{* * *}$ & $13.249^{*}$ & $0.348^{* *}$ & $1.094^{* * *}$ & $0.681^{* * *}$ & 0.588 & 0.031 & $1.210^{* * *}$ & $0.713^{* * *}$ \\
\hline Conflict resolution \& change & 0.155 & $0.498 * * *$ & 0.948 & 0.041 & $0.362^{* *}$ & $0.303^{* * *}$ & $-1.613^{* * *}$ & $0.711^{* * * *}$ & $0.332 * *$ & 0.028 \\
\hline Responsibility \& ties & 0.113 & $0.296^{*}$ & $3.797^{*}$ & $0.375^{* *}$ & 0.120 & $0.250^{* *}$ & -0.533 & -0.270 & $0.307^{* *}$ & $0.367^{*}$ \\
\hline$R$-squared & 0.251 & 0.251 & 0.737 & 0.140 & 0.304 & 0.233 & 0.500 & 0.301 & 0.262 & 0.300 \\
\hline
\end{tabular}

